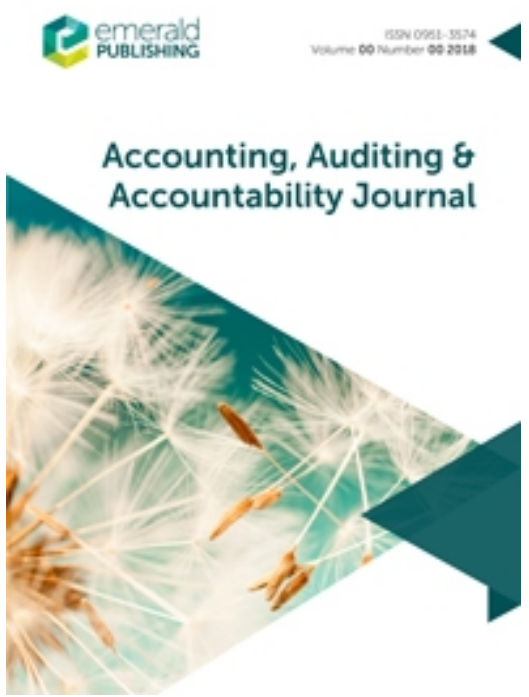

Old ways and new means: Indigenous accountings during and beyond the pandemic

\begin{tabular}{|r|l|}
\hline Journal: & Accounting, Auditing \& Accountability Journal \\
\hline Manuscript ID & AAAJ-08-2020-4753.R2 \\
\hline Manuscript Type: & Research Paper \\
\hline Keywords: & Barter, Indigenous, South Pacific, Alternative Accounts, COVID-19 \\
\hline \multicolumn{2}{|l}{} \\
\end{tabular}

SCHOLARONE $^{\text {TM }}$

Manuscripts 


\section{Old ways and new means: Indigenous accountings during and beyond the pandemic}

\section{Purpose}

The study uses the case of an online-mediated barter economy that proliferated during the COVID-19 crisis to highlight Indigenous notions of barter, trade and exchange.

\section{Methodology}

A netnographic approach was employed which involved collecting online posts and comments which were stored and analysed in NVivo. This was supplemented with field notes and reflections from authors with an intimate knowledge of the context. These were analysed thematically. The overall methodology is inspired by decolonising methodologies that seek to restore the agency of Indigenous Peoples in research towards self-determination.

\section{Findings}

Findings suggest that during and beyond the crisis, social media (a new means) is being used to facilitate barter and determinations of/accounting for value within. This is being done through constant appeals to, and adaptation of, tradition (old ways). Indigenous accounting is therefore best understood as so through Indigenous accountability values and practices.

\section{Originality value}

We propose a re-orientation of accounting for barter research that incorporates recent debates between the disciplines of economics and anthropology on the nature of barter, debt and exchange. We also propose a re-imagining of accounting and accountability relations based on Indigenous values within an emerging online barter system in Fiji during COVID-19 as 'old ways and new means' to privilege Indigenous agency and overcome excessive essentialism.

\section{Keywords:}

Barter, COVID-19, South Pacific, Alternative Accounts, Indigenous.

\section{Article Classification:}

Research Paper

\section{Acknowledgements}

We would like to acknowledge the administrators of the Barter for Better (Fiji) page for supporting our research. We also would like to thank Heather Horst, Geir Presterudstuen, Romitesh Kant, Jason Titifanue, Stewart Smyth, Markus Milne, Jan Bebbington, Steven Ratuva, Kylie Kingston, and Jesse Dillard for reading and commenting on iterations of the paper. Their various insights were all invaluable to its development, as was the constructive feedback from two anonymous reviewers. 


\section{Introduction}

While the impacts of COVID-19 have been pervasive, some regions and peoples have suffered disproportionately. Fiji is in a state of economic despair as the economy relies heavily on tourism (40\% of GDP and 25\% of employment (Fiji Bureau of Statistics, 2017; Author, Year)). The economic fallout from the halting of tourism has led to mass layoffs with the government stating that it requires radical financing in order to survive the crisis (Fiji Village, 2020). While many developed countries have announced unprecedented economic rescue packages to stimulate the economy, developing countries, including Fiji, are not well-resourced to implement such stimulus packages. The travel ban, high unemployment, lack of liquidity and lack of government support paint a grim picture for Fiji.

Despite this grim picture, something hopeful has emerged. A new barter economy facilitated through Facebook has flourished within Fiji and has been adopted by other Pacific countries (Boodoosingh, 2020; Fogarty, 2020). "Barter for a Better Fiji" (BFBF) was created by a group of women who saw the possibility of bartering as a means to help cash-strapped Fijians receive essential goods (Tora, 2020). While most Fijians have had their incomes reduced and thus face a shortage of money, the new bartering system allows them to obtain goods for the exchange of other goods or the provision of services (Fogarty, 2020). However, this system is practised within a wider set of accountability relations that privilege kinship and reciprocity.

The present study explores the emergence of, and practices within, BFBF as an Indigenous alternative to accounting and accountability relations. We argue that this response to the COVID19 crisis is a contemporary contextualised manifestation of enduring Indigenous Fijian practices and thus informs us of alternative past, present and future possibilities for accounting. COVID19 has forced Fijians to abandon systems embedded in the economic ideologies of free-market capitalism introduced through colonial power relations, and adopt systems informed by Indigenous values and practices of trade and exchange. This suggests that these practices are neither 'old' nor 'new' but 'old ways and new means' (Anderson, Binney and Harris, 2013). We argue along these lines that orthodox traditionalism (Hogan, 2000; Reid and Rout, 2016) represents a necessary intervention in the accounting literature to enhance understanding of Indigenous Peoples, accounting and colonialism. Orthodox traditionalism says that a key trait of Indigeneity is the capacity for radical adaptation and embraces external ideas and technologies through enduring values and practices embedded in Indigenous tradition. The contribution of this study is therefore two-fold. We empirically explore practices of an alternative form of accounting, inspired by Indigenous traditions as an alternative during crisis, and we theoretically suggest orthodox traditionalism overcomes some of the excessive essentialism inherent in previous studies.

\section{Indigenous Peoples, accounting, and barter}

In this section we briefly explore the literature on Indigenous Peoples, accounting and barter and argue that the present case is better conceptualised as a contemporary contextualised Indigenous practice. Doing so is important for the following reasons. Firstly, Indigenous Fijian history was primarily orally transmitted and most of this history was destroyed or repackaged by European missionaries who sought to "civilise" and convert Indigenous Fijians to Christianity (Tomlinson, 2009) and capitalism. Secondly, the Fijian histories that have been recorded or presented have been written by Western academics who can project biases and construct histories through lenses that are incomplete and/or inaccurate (Hau'ofa, 1993; Thaman, 2003). All of this has worked towards obscuring and erasing the agency of Indigenous Peoples within, against, and beyond colonialcapitalism. This lack of agency has been replicated in the accounting literature (see e.g. Buhr, 2012; Author, Year) and to counter this we envisage the emerging barter practices of our case study as a contemporary contextualised Indigenous accounting. 
Academic debates around barter have existed since at least the time of Aristotle as an attempt to understand theories of exchange, trade and money. Economists such as Adam Smith and Carl Megner argue that barter was a precursor to money and was eventually abandoned after society realised the efficiencies of money as a superior medium of exchange. However, some anthropologists have rejected this notion and argue that there is no ethnographic evidence to suggest the existence of a pure barter economy (Humphrey and Hugh-Jones, 1992). Graeber (2012) argues that the "myth of barter" was constructed by economists to reinforce their ideology that relied on the natural progression from barter to the use of money. A sort of normative developmentalism that suggests a linear progress from primitive to civilised. Barter was portrayed as primitive or uncivilised as part of larger colonial power relations because it presents a viable non-capitalist form of exchange and by extension an alternative mode of production. Barter had to be ideologically eradicated to make way for colonial-capitalism.

Other barter debates are definitional. While economists generally define barter as a commodity exchange between different parties (Starr, 1989), anthropologists have distinguished between commodity exchange and barter (Gregory, 1982). The distinction being that a commodity exchange is purely a commercial transaction whereas barter is embedded in social relations. Accounting studies have tended to adopt the definition and view of economists in relation to barter as a precursor to money (De Ste, 1955), a commodity exchange (Capozzoli and Teed, 2016) and a largely primitive practice (Stone, 1985). Early work on accounting and barter is primarily historic in nature and examines barter practices in ancient Greece and Rome (De Ste, 1955), Colonial America (Baxter, 1955), Colonial Canada (Spraakman and Wilkie, 2000), Colonial Australia (Carnegie, 2004; Parker, 1982) and 17 ${ }^{\text {th }}$ century Europe (Lai, Leoni, and Stacchezzini, 2012). These have sought to prescribe a method of accounting for barter (Stone, 1985) or describe barter accounting practices as the ascription of monetary values to barter transactions (Carnegie, 2004; Parker, 1982). Unlike most other papers on accounting and barter, Lai et al. (2012) do not highlight how to account for barter but rather analyse the way accounts were used in rejecting a proposed barter. They use the case of a proposed barter between two states to examine broader issues of accounting and government, and how government actors use accounts to make visible, and thus governable, individuals, groups and organisations.

Contemporary barter is generally a response to economic crises and can take different forms (see e.g. Humphrey and Hugh-Jones, 1992; Philip, Ozanne and Ozanne, 2016; Ozanne and Ballantine, 2019). Local Exchange Trading Systems (LETS) - a form of extended barter - emerged in Canada and made their way to the United Kingdom as a popular method for exchanging goods and services through a currency created by the system (Bebbington, 2010). Bebbington (2010) introduces the concept of LETS to the accounting literature and draws linkages between LETS and accounting that include understanding calculative accounts, the application of tax regimes and sustainable economic development. The LETS initiative and the BFBF page emerged out of similar circumstances - economic crises causing widespread unemployment and scarcity of cash and have similar objectives which, while economic in nature, are primarily motivated to promote social cohesion and self-reliance.

We broadly follow the approach by Bebbington (2010) and Lai et al. (2012) where a barter system is used as a case study to explore broader issues related to accounting and accountability. Our use of accounts is also not related to structured systems of book-keeping but broader and alternative notions of value. We therefore explore the specific practices of barter within BFBF as accounting practices that determine values, but within a wider accountability system based on kinship and reciprocity. The BFBF page is not merely a response to the pandemic but to the globalisation of capital that has been historically disadvantageous to the majority of the world's population and particularly to Indigenous Peoples. In doing so, we firmly place the agency of self-determining Indigenous futures within the hands of Indigenous Peoples. 
At a fundamental level the critiques around agency and barter emerge from a tendency towards an 'excessive essentialism' or false dichotomy between Indigenous and West, traditional and contemporary, old and new. It follows from a normative developmentalism that suggests a linear transition from primitive to civilised and locks Indigenous traditions firmly in a past, pure form. This ignores the reality of dynamic Indigenous adaptation in the face of colonialism and other forces (Simpson, 2011; Coulthard, 2014; Reid and Rout, 2016). Adaptation while maintaining a sense of self through enduring practices and values is a central element of Indigenous agency in the colonial context (Stevens, 2015). Although Indigenous agency is present throughout history, it has been constrained and contained by colonialism, which has done its best to construct the rigid false dichotomy between Indigenous and West as a form of control and erasure.

Orthodox traditionalism does not remain committed to either an 'old' static identity, or a 'new' hybrid identity, but embraces external ideas and technologies through values and practices embedded in Indigenous tradition (Hogan, 2000, Reid and Rout, 2016). In this manner, the values and practices of Indigenous tradition endure, but the forms representing the tradition and the tools to do so change. However, tools do not define Indigeneity (Simpson, 2017). While new tools may be added to Indigenous practices, these practices can remain deeply embedded in a wider cultural frame (Stevens, 2015; Simpson, 2017). Simpson (2011) argues for a reorientation from transforming the colonial outside into a flourishment of the Indigenous inside. This does not "literally mean returning to the past," "but rather re-creating the cultural and political flourishment of the past to support the well-being of our contemporary citizens" (Simpson, 2011, as cited in Coulthard, 2014, p.156). For Simpson this requires that Indigenous Peoples reclaim "the fluidity of our traditions, not the rigidity of colonialism" (Simpson, 2011, as cited in Coulthard, 2014, p. 156).

It is thus necessary to take orthodox traditionalism seriously in the analysis of Indigenous accounting practices to move beyond the dichotomy. Recently Indigenous authors have taken a nuanced approach to Indigenous resurgence and economic development that embraces new ideas and tools, but through a flexible Indigenous ontology (Simpson 2011; 2017; Coulthard, 2014; Stevens, 2015; Reid and Rout, 2016). This represents a duality capable of delving into tradition, with new tools to confront new challenges as well as acknowledging Indigenous innovation (Stevens, 2015; Simpson, 2017). Orthodox traditionalism is thus a means and an end to confront colonialism and create alternative Indigenous futures. The combination of these perspectives make up the thrust of our argument to support BFBF as an Indigenous accounting.

\section{Methodology}

We adopt a netnographic approach to explore and conceptualise BFBF and the practices within as Indigenous accounting(s). Netnography is a qualitative research methodology that has been referred to as ethnography of the internet as it adapts ethnographic techniques to the study of communities and cultures that emanate through computer-mediated communications (Kozinets, 2010). In a guide for accounting researchers, Jeacle (2020) identifies three forms of data that can be collected from netnographic research. These are passive (purely monitoring and observing), active (co-created data) and reflexive (reflexive field notes from online observation). This study adopts a mix of the first and third approach. While data was collected from Facebook in a passive way, reflexive notes were kept as part of an abductive engagement between data and existing literature and theoretical perspectives (Smith, 1999).

Initial data collection was done by the first author, who is an Indigenous Fijian that has been living in Australia for the last four years. There is a large Fijian diaspora in Australia and New Zealand and Facebook is the main medium by which Fijians and Pacific Islanders generally keep up-todate with news and maintain relationships with family in the islands (Titifanue et al. 2018). For the first author, joining and following the BFBF page almost immediately after its inception was a personal way to keep up with COVID-19 response in Fiji despite being stuck in Australia due to 
lock-down and border restrictions. The second author is based in Aotearoa New Zealand and identifies as Māori (Kāi Tahu) and Pākehā (European settler). Both authors therefore identify as Indigenous Pacific Islanders, and commit to Indigenous Pacific ontologies, epistemologies and methodologies (see e.g. Hau'ofa, 1993; Smith, 1999; Stevens, 2015). Our familiarity with the social media landscape and Indigenous/Pacific ways of knowing informed the collection, analysis and interpretation of data for this study.

Previously, Facebook data could be collected using software such as Facepager and apps such as Netvizz which allowed researchers to download posts, reactions and comments from Facebook pages (Rieder 2013). However, following the Cambridge Analytica Scandal, Facebook changed their API (Application Programming Interface) to restrict access to data. Apps such as Netvizz could no longer fetch data from Facebook and software such as Facepager can still fetch data but only from public pages. BFBF was initially a public page but due to fake accounts posting unrelated messages, the administrators changed the privacy setting to private and began reviewing each request to join. This was to ensure the authenticity of members and posts. Members who breached any of the page's policies were removed from the page. Because of the changes in Facebook's policy which prevented the use of software to collect and scrape data from private Facebook pages, the data for the paper was collected manually by "snipping" the images of posts and copying the text of the post to NVivo. Most of the trades incorporated text, images and even videos of people marketing their goods and services or sharing images, stories and videos of successful trades.

The first author collected data between 18 May 2020 and 10 August 2020. This was coded based on broad themes from a review of the literature and with emergent themes from the data. These thematic categories of data were then analysed by both authors and the final key themes were extracted from the data to form the basis for this paper. Table 1 below provides a summary of the key themes derived from the coding process.

\section{Table 1 about here}

During the data collection process, the first author kept notes and reflections on posts and comments around posts. These notes and reflections contributed to the abductive thematic analysis process as the particularities of the Indigenous context were clarified between authors. Data was then anonymized in line with rapidly developing ethical guidelines around social media use (Jeacle, 2020). The thematic categories that emerged from data and reflective field notes were also applied to popular news articles about the page. During our analysis and its presentation we have tried to balance the calls for transparency (Aguinis and Solarino, 2019) and trustworthiness (Pratt et al., 2020) with time and word limitations. We have done this by focusing on the transparency criteria of contextualizing the research setting, positioning ourselves as researchers in the insider/outsider continuum, clarifying our sampling procedures and emphasising the relative importance of the participants. These criteria align with decolonising/Indigenous methodologies that privilege Indigenous perspectives towards self-determination (see e.g. Hau'ofa, 1993; Smith, 1999; Stevens, 2015). In the next section, we present the findings of this analysis.

\section{Old ways and new means: Indigenising accounting}

In this paper, we examine the case of a barter economy that has emerged in Fiji during the COVID19 crisis. Barter economies typically arise from periods of crisis when money becomes scarce (Carnegie, 2004). The barter economy in Fiji is no exception, however, how this barter economy was initiated and how it has flourished is quite different to previous studies as the barter economy was initiated through a Facebook page called "Barter for a Better Fiji" (BFBF). The page was created by a Fijian woman named Marlene Dutta who established the page as a potential solution 
to the current economic situation affecting Fijians (Tora, 2020). The Government of Fiji estimates that 115,000 Fijians, almost a third of the total labour force, are unemployed or on reduced hours as a result of the pandemic (Government of Fiji, 2020). The economic crisis led to a scarcity of cash and for Fijians to find alternative means to access essential goods and services. BFBF emerged out of this crisis.

Within weeks of the page being created, close to 100,000 (one-tenth of Fiji's population) people had joined the public group and stories of the page have appeared in numerous international media outlets (Fogarty, 2020; Tora, 2020). At the time of writing, there are 186,988 members. During the height of the crisis there were thousands of posts per day (Fogarty, 2020). While the new barter economy was initiated because of the crisis, there are also cultural and social factors that led to the barter economy being so successful within Fiji (Boodoosingh, 2020). Multiple systems of exchange existed in the ancient pacific from gift economies, barter and even pre-metallic money (Jiko, 1993). Barter was observed in ancient Fiji when Fijians used to barter bark cloth for sandalwood with Tongans (Jiko, 1993). While facilitated by new technologies, the barter economy emerging in contemporary Fiji is the revival of ancient trade practices and thus offer insights into Indigenous accounting.

The stated aim of the page is "Nurturing a community of kindness through bartering" and by joining the group, participants agree to abide by Group Guidelines. The parameters for barter are firmly established by the group admins and these can be seen as facilitating alternatives, but within existing legal systems. These include exchanging within curfew/lockdown restrictions, non-cash only, no illegal items, maintaining trades within local areas to reduce travel, value decided between traders, freely given and fair, delivery organized between trading partners, and the page itself is not responsible for trades but anyone breaking rules will be asked to leave and if necessary, reported to authorities.

While the page is a contemporary practice, that emerged to fill the gaps in the dominant mode of production challenged by COVID-19, it is also explicitly looking backwards to ancestors for guidance:

So, back in the before, when money was sooo tomorrow, our ancestrals lived by exchanging what they had for what they needed. Easy eh? How about we do that again now?" (FB1).

"Back in the village now as we are talking people are still doing barter..." "...for me I said this is who I am this is what my people have been doing and are still doing it." - Ender Rence (Fogarty, 2020)

"Barter system is something our forefathers did back in the day," she said, "I thought you know what I am surrounded by a lot of coconut trees and we can make brooms out of coconut leaves." - Joyce Tokainamua (Fogarty, 2020)

Our specific findings in relation to this page as an Indigenous accounting practice revolve around value and values. Value as the practices within the page of determining value, and values as the social and cultural system within which value determination is embedded. The parameters of both value and values are contested within the page given the contemporary context of colonization that has disrupted the original economic instructions (Reid and Rout, 2016) and they are being pieced back together to look forward in this crisis.

Value

In the BFBF page, initial trades mostly comprised of individuals exchanging unwanted or excess items for other items or groceries. Mothers used the page to barter their baked goods for baby items such as diapers and baby's milk. Traders then began offering services for groceries. These services included IT-related services, garden cleaning services and medical services (Tora, 2020). However, a common issue raised by admins and members of the group is the rejection of money 
or the use of monetary figures in the valuation of items being bartered. These tended to arise under particular power relations where some were not getting a 'fair' deal, with some taking advantage of the desperation of others. Many made these complaints by comparing back to specific monetary values of commodities. Administrators explicitly rejected the use of monetary valuation, and one response from a poster was:

Please do not compare what you would get from barter if you using $\$$. Remember barter system was used for trading in the olden days when there was no currency involved so it doesn't really matter what you get in return but as long as both traders agree with whatever they deal with.

What tended to ensue from these discussions were debates about honesty and responsibility of people within barter transactions, this is when accountability relations, embedded within Indigenous traditions, overtook contemporary forms of value and valuation as norms of behavior. The same poster above appealed to traditional forms of exchange that could now be viewed as exploitative, particularly those between Indigenous Fijians and Europeans. One lens may suggest an unequal exchange, another may suggest a gift, and others may suggest different forms of property rights could also come into play. A poster responded to this appeal with:

our ancestors didn't know what we do now in terms of value... and how we wish they had! Not everything has to be about money, integrity is something l'd vouch for.

Here a poster is questioning the wisdom of the ancestors in these cross-cultural trades which resulted in land loss within the context of colonization. However, another poster appealed to the wider accountability frame within which these exchanges occurred to bring it back to values:

Segaiii (NOOOOO) that's in the older days..life is different and hard... meda dau veinanumi ga (we should always think of each other) and ensure whatever you are giving in exchange for the barter product is comparable to what you are getting...na nomu dina ena nomu vaitavi na (your honesty is your responsibility) to the barter system.

Another example includes a poster describing their barter in great detail including interactions around it. The initial barter was calves for plants, but in the post, many were thanked including someone who helped negotiate 'prices" with the conclusion that "we may not barter for goods, but we could barter for the access for better prices." He then commented "I don't think we're bartering anymore, we're just giving..lol" A response to this post was "Amazing bartering to another level: veisolevuti". Veisolevuti - comes from the root word "Solveu" which is a traditional gift-giving ceremony between villages (Thompson, 1949). Not only does it facilitate trade but it is an efficient and self-regulatory mechanism to stimulate production to expand systems of distribution - it effectively facilitates growth through exchange embedded within social traditions (Thompson, 1949).

This leads us to our first substantive point that social media (a new means) is being used to facilitate barter in the contemporary context, and determinations of value within, with constant appeals and adaptations for tradition (old ways). However, this substantive point is more fully understood by exploring the values being appealed to within tradition, that is, to understand this as an Indigenous accounting, we must explore Indigenous accountability.

Values

Specific practices of accounting for value can best be understood through the traditions that these traders are drawing from and evolving in the contemporary context. Three key concepts to help understand this are veisa, kerekere and bulubulu. According to one poster, veisa is a transaction/act of exchange and the ancestors of iTaukei (Indigenous Fijians) practiced veisa in economic, political and social settings. Veisa birthed out of a value for reciprocity as a way to strengthen relationships, social cohesion and security. Above all, it is about connections and provides connectedness to unseen Gods, neighbors or the environment. However, this practice has been distorted by colonization, urbanization and globalization. Kerekere, according to the same poster is a transaction 
but in the form of a loan paid back with interest. This meant that in paying back (or possibly forwards) the goods, the value or volume would be more than was borrowed, parties would agree on a time for payment and this could be a year or more. Finally, a bulubulu or atonement is required to chase away a malignant spirit of the dead that has arisen if the kerekere was not honoured. It is easier to understand how a bartering system would fit within this system of reciprocal accountability than through a purely economic lens, that is itself a particular culturally constituted value/accountability system.

For example, in a post regarding the trade of a stroller for fish and mud lobster, the poster recounted their trade and the realization that they had particular kinship links during the trade. This connection resulted in one trader giving the other a lift home in her car because "Ei, kedaru sa koro vata (Hey, we from the same village)". The post highlighted the addition to the transaction of a veitauvu relationship. Veitauvu is a traditional relationship that exists between iTaukei from certain provinces (Toren, 1999). This suggests the additional outcome of the initial trade of commodities, is a reconnection with social and kinship relations, the benefits for the self of giving, and learning something new.

Despite this, there are always challenges bringing old traditions back to life through new means. Critics suggest that Facebook is not necessarily the best way to mediate these exchanges because it extracts the practice out of the traditions. One poster suggested that if those involved in barter have not been to villages and understand the enduring traditions then they might not be best placed to be part of or administer these exchanges. This sort of approach is common in decolonising contexts and revolves around a village versus urban divide. Those raised in urban contexts have been alienated from village traditions. This is one example of the complexity of trying to contextualize the original economic instructions into a contemporary moment.

We can therefore think of the specific practices of determining value in BFBF as a contemporary contextualized Indigenous accounting. This is facilitated by old ways (the reciprocal traditions of ancestors) and new means (social media) but can best be understood as so if placed within the accountability systems embedded in values. This brings us to our second substantive point that accounting practices be examined within the wider accountability relations within which they occur.

\section{Discussion and concluding thoughts}

COVID-19 has revealed the fragility and contradictions of colonial-capitalism, and this has been particularly severe in Pacific Island countries, where this mode of production was introduced forcibly through colonialism. However, Roy (2020) and others have suggested that now is the time to stop and imagine what an alternative future could look like - "the pandemic is a portal" (Roy, 2020). We have taken these calls as inspiration to conceptualise and explore Barter for a Better Fiji as a contemporary contextualised Indigenous accounting and accountability system that draws on old ways and new means for other possible futures. The contribution of this short study is therefore twofold, with the empirical novelty of this alternative response to accounting and accountability practices during and beyond COVID-19, and a theoretical contribution of old ways and new means that opens up the radical potential of Indigenous alternatives as facilitating selfdetermination and alternative accounting practices within, against and beyond colonial-capitalism.

Drawing on recent anthropological work around barter (Graeber, 2012), and orthodox traditionalism (Logan, 2000; Reid and Rout, 2016), we argue that the emergence of a new barter economy in Fiji is not merely one of crisis-driven desperation for exchange of goods. Instead, it is deeply influenced by kinship and reciprocity, and the need to build a sense of community and solidarity during and beyond the COVID-19 crisis. The case highlights non-capitalist notions of exchange that are difficult to categorise into commodity exchanges, barter and gifts. This further highlights the complexities of accounting for exchanges with cultures whose notions of exchange 
differ from capitalist notions of exchange where commodities are alienable. Accounting practices and accountability relations of trade and exchange are dependent on the participants, the relationship between the participants, the objects, and the social milieu during the exchange. The paper thus initiates a conversation on imagining new forms of accounting and accountability relations that match the original economic instructions (old ways) with technological innovations (new means).

We have illustrated how excessive essentialism can manifest into a rigid dichotomy between Indigenous and West that sees traits of Indigeneity locked in time and form (Reid and Rout, 2016). This has the potential to suggest that either Indigenous Peoples are forced to practice these traits in their fixed position forever, or they are no longer Indigenous. If instead we reconceptualise that Indigenous practices and beliefs evolve over time while individuals and groups maintain a sense of individual and collective self-recognition, then Indigenous Peoples can adapt within a contemporary context (Simpson, 2011; 2017; Coulthard, 2014; Stevens, 2015; Reid and Rout, 2016). The enabling potential for Indigenous accounting is adapting the forms of practices while maintaining a set of enduring values in a contemporary context - orthodox traditionalism (Hogan, 2000; Reid and Rout, 2016). New forms of accounting by Indigenous Peoples must be embedded within their value systems (Author, Year). Case studies of Indigenous forms of accounting can inspire alternative accounting and accountability structures both for Indigenous and nonIndigenous peoples who share the same goals. This paper thus adds to the sparse literature on accounting by Indigenous Peoples.

The pandemic is a portal to question current trajectories and imagine alternatives (Roy, 2020). At the same time, we must be cognisant and sensitive to this destruction as contemporary livelihoods are strained. This potential for alternatives presents significant opportunities for future research and practice. This could include critically engaging with the role of Facebook in facilitating or coopting these practices, the accounting and information systems that could be developed for alternative accountings, and more deeply exploring and privileging accountability as a set of values and relationships (Dillard and Vinnari, 2019). We encourage accounting authors to continue to open our minds to what constitutes accounting, and what constitutes accountability, because things are evolving rapidly. Alternatives will be within, against and beyond what we currently conceptualise as accounting and accountability relations. 


\section{REFERNCES}

Aguinis, H. and Solarino, A. M. (2019), "Transparency and replicability in qualitative research: The case of interviews with elite informants", Strategic Management Journal, Vol. 40 No. 8, pp.1291-1315.

Anderson, A., Binney, J. and Harris, A. (2016), Tangata Whenua, Bridget Williams Books: Wellington, New Zealand.

Author. A. (Year). Referenced removed for anonymity

Author. B. (Year). Reference removed for anonymity

Baxter, W. T. (1956), "Accounting in Colonial America”, In Littleton, A. and Yamey, B. (Eds.), Studies in Accounting History, Sweet and Maxwell, London, England, pp.272-87.

Bebbington, J. (2010), "Local exchange trading systems (LETS): An introduction", Social and Environmental Accountability Journal, Vol. 21 No. 1, pp.12-18.

Boodoosingh, R. (2020), "Bartering in Samoa during COVID-19", DevPolicy Blog, available at: https://devpolicy.org/bartering-in-samoa-during-covid-19-2020630-1/ (accessed 12 Aug 2020).

Buhr, N. (2011), "Indigenous Peoples in the accounting literature: time for a plot change and some Canadian suggestions", Accounting History, Vol. 16 No. 2, pp.139-160.

Capozzoli, E. A., and Teed, D. G. (2016), "Post-Civil War accounting practices in Natchez, Mississippi", Accounting Historians Journal, Vol. 43 No. 2, pp.39-58.

Carnegie, G. D. (2004), "Re-examining the determinants of barter accounting in isolated communities in colonial societies", Accounting History, Vol. 9 No. 3, pp.73-87.

Coulthard, G. (2014), Red skin, white masks, University of Minnesota Press, Minneapolis, MN.

De Ste, G. E. M. (1955), Greek and Roman accounting. London: Sweet \& Maxwell.

Dillard, J. and Vinnari, E. (2019), "Critical dialogical accountability: From accounting-based accountability to accountability-based accounting", Critical Perspectives on Accounting, Vol. 62, pp.16-38.

Facebook. (2020), Barter for a Better Fiji. Available at: https://www.facebook.com/groups/2964591663604507/ (accessed 12 Aug 2020).

Fiji Bureau of Statistics. (2017), "Fiji Bureau of Statistics", available at: https://www.statsfiji.gov.fj/ (accessed 12 Aug 2020).

Fiji Village. (2020), "We will require radical financing solutions - Bainimarama", available at: https://www.fijivillage.com/news/We-will-require-radical-financing-solutions-Bainimarama-58x4rf (accessed 12 Aug 2020)

Fogarty, N. (2020), "Ancient bartering system finds new life on Facebook", Australia Broadcasting Commission, available at: https://www.abc.net.au/radioaustralia/programs/pacificbeat/barter-for-better-fiji/12214544 (accessed 12 Aug 2020).

Government of Fiji. (2020), Economic and Fiscal Update Supplement to the 2020-2021 Budget Address.

Graeber, D. (2012), Debt: The first 5000 years, Palgrave, New York, NY.

Gregory, C. A. (1982), Gifts and commodities, HAU Books, London, England.

Hau'ofa, E. (1993), "Our sea of islands", Waddell, E., Naidu, V. and Hau'ofa, E. (Eds.), A new Oceania: Rediscovering our sea of islands, University of the South Pacific Press, Suva, pp.2-16.

Hogan, P. (2000), Colonialism and Cultural Identity: Crises of Tradition in the Anglophone Literatures of India, Africa and the Caribbean, State University of New York Press, Albany, NY.

Humphrey, C., and Hugh-Jones, S. (1992), Barter, exchange and value: an anthropological approach: Cambridge University Press, England.

Jeacle, I. (2020), "Navigating netnography: A guide for the accounting researcher." Financial Accountability \& Management. In Press. DOI: https://doi.org/10.1111/faam.12237

Jiko, L. (1993), "Status and current interest in sandalwood in Fiji”, McKinnell, F. (Ed.), Sandalwood in the Pacific Region, Canberra: ACIAR, pp.13-18).

Kozinets, R. V. (2010), Netnography: Doing ethnographic research online. SAGE, Los Angeles, CA. 
Lai, A., Leoni, G., and Stacchezzini, R. (2012), "Governmentality rationales and calculative devices: The rejection of a seventeenth-century territorial barter proposed by the King of Spain", Accounting History, Vol. 17 No. 3-4, pp.369-392.

Ozanne, L.K., and Ozanne, J. L. (2016), "How alternative consumer markets can build community resiliency", European Journal of Marketing Vol. 50 No. 3-4, pp.330-357.

Parker, R. (1982), "Bookkeeping barter and current cash equivalents in early New South Wales", Abacus, Vol. 18. No. 2, pp.139-151.

Philip, H., Ozanne, L., and Ballantine, P. (2019), "Exploring online peer-to-peer swapping: A social practice theory of online swapping", Journal of Marketing Theory and Practice, Vol. 27 No. 4, pp. 413-429.

Pratt, M. G., Kaplan, S., and Whittington, R. (2020), "Editorial essay: The tumult over transparency: Decoupling transparency from replication in establishing trustworthy qualitative research", Administrative Science Quarterly, Vol. 65 No. 1, pp.1-19.

Reid, J. and Rout, M. (2016), "Māori tribal economy: rethinking the original economic institutions", available at: https://ir.canterbury.ac.nz/handle/10092/12391 (accessed 12 August 2020).

Rieder, B. (2013), "Studying Facebook via data extraction: the Netvizz application." Proceedings of the 5th annual ACM web science conference. DOI: https://doi.org/10.1145/2464464.2464475

Roy, A. (2020), "The Pandemic Is a Portal." Financial Times, available at: https://www.ft.com/content/10d8f5e8-74eb-11ea-95fe-fcd274e920ca (accessed 12 August 2020).

Simpson, L. B. (2011), Dancing on our Turtle's back: Stories of Nishnaabe re-creation, resurgence, and a new emergence, ARP Books, Winnipeg, Canada.

Simpson, L. B. (2017), As we have always done: Indigenous freedom through radical resistance, University of Minnesota Press, London, MA.

Smith L.T. (1999), Decolonizing methodologies: Research and Indigenous Peoples. University of Otago Press, Dunedin, New Zealand.

Stevens, M. (2015), “A 'useful' approach to Māori history”, New Zealand Journal of History, Vol. 49 No. 1, pp.54-77.

Spraakman, G., and Wilkie, A. (2000), "The development of management accounting at the Hudson's Bay Company, 1670-1820”, Accounting History, Vol. 5 No. 1, pp.59-84.

Starr, R. M. (1989), "The structure of exchange in barter and monetary economies", Quarterly Journal of Economics, Vol. 86 No. 2, pp.290-302.

Stone, W. E. (1985), "Barter: Development of accounting practice and theory", Accounting Historians Journal, Vol. 12 No. 2, pp.95-108.

Thaman, K. H. (2003), "Decolonizing Pacific studies: Indigenous perspectives, knowledge, and wisdom in higher education", The Contemporary Pacific, Vol. 15 No.1, pp.1-17.

Thompson, L. (1949), "The relations of men, animals, and plants in an island community (Fiji)", American Anthropologist, Vol. 51 No. 2, pp.253-267.

Titifanue, J., Rufino, R. V., Renata, V., Romitesh K., and Finau, G. (2018), "Digital diaspora, reinvigorating Indigenous identity and online activism: social media and the reorientation of Rotuman identity." Media International Australia Vol. 169 No. 1, pp.32-42.

Tomlinson, M. A. (2009), In God's image: the metaculture of Fijian Christianity, Univ of California Press, Los Angeles, CA.

Tora, T. (2020), Two piglets for a kayak: Fiji returns to barter system as Covid-19 hits economy. The Guardian. Available at: https://www.theguardian.com/world/2020/may/08/twopiglets-for-a-kayak-fiji-returns-to-barter-system-as-covid-19-hits-economy (accessed 12 August 2020).

Toren, C. (1999), "Compassion for one another: Constituting kinship as intentionality in Fiji", The Journal of the Royal Anthropological Institute, Vol. 5 No. 2, pp.265-280. 


\begin{tabular}{ll}
\hline Theme & Description \\
\hline Interpretations of & - Posts that related to how Fijians interpreted Barter/Barter \\
Barter/Barter Economy & Economy \\
& - Posts that highlighted the differences between Indigenous \\
& and non-Indigenous interpretations of Barter/Barter \\
& economy \\
\hline Value & - Posts related to how traders interpreted and negotiated the \\
& values of exchange in barter transactions \\
& - Posts that highlighted the conflicts and tensions when \\
& valuing goods in a barter transaction \\
\hline Values & - Posts which highlighted the values embodied with the \\
& bartering and specific trades \\
\hline
\end{tabular}

